\title{
HUBUNGAN KOMUNIKASI TERAPEUTIK PERAWAT TERHADAP KEPUASAN PASIEN DI RUMAH SAKIT MARTHA FRISKA MEDAN
}

\author{
Abdul Hanif Siregar* Syarif Zein Yahya* \\ Dosen Jurusan Keperawatan Poltekkes Kemenkes Medan
}

\begin{abstract}
Abstrak
Komunikasi terapeutik adalah komunikasi yang direncanakan secara sadar antara perawat dan pasien yang kegiatannya dipusatkan untuk kesembuhan pasien. Penelitian ini bertujuan untuk menganalisis sejauhmana pengaruh komunikasi terapeutik terhadap kepuasan pasien dalam pelayanan asuhan keperawatan di ruang rawat inap rumah sakit Martha Friska Medan. Penelitian ini menggunakan rancangan study korelasi dengan pengambilan sampel 25\% dari jumlah populasi sebanyak 640 orang pasien rawat inap rumah sakit Martha Friska Medan. Hasil penelitian didapatkan bahwa penerapan komunikasi terapeutik di ruang rawat inap rumah sakit Martha Friska Medan sudah optimal. Ditinjau dari adanya keterbatasan yang dimiliki dalam diri perawat seperti respon dan empati pada sebahagian perawat yang masih kurang dan kurang melaksanakan Standar Operasional Prosedur (SOP) mengenai komunikasi terapeutik. Untuk kepuasan pasien yang dirawat inap di rumah sakit Martha Friska Medan, pada umumnya pasien merasa sangat puas atas pelayanan yang diberikan oleh perawat bila ditinjau dari respon dan empati perawat ketika berinteraksi dengan pasien. Berdasarkan uji analisis Spearman'n Correlation pada penelitian ini menunjukkan nilai $\mathrm{r}=0,004$. Dan $\mathrm{P}=0,972$ yang berarti tidak terdapat pengaruh yang signifikan antara komunikasi terapeutik perawat dengan kepuasan pasien. Berdasarkan hasil. penelitian tersebut disarankan bagi perawat meningkatkan pelaksanaan komunikasi terapeutik yang sudah berjalan dengan baik dan bagi pihak rumah sakit membuat SOP komunikasi terapeutik, meningkatkan pengetahuan perawat dengan cara mengikutsertakan para perawat dalam seminar-seminar keperawatan tentang komunikasi terapeutik, memberikan pelatihan untuk meningkatkan sikap empati perawat terhadap pasien, dan memberikan kesempatan perawat melanjutkan pendidikannya.
\end{abstract}

Kata kunci : Komunikasi Terapeutik, Kepuasan Pasien

\section{PENDAHULUAN}

Menurut Kotler (1988) kepuasan adalah tingkat kepuasan seseorang setelah membandingkan kinerja atau hasil yang dirasakan dibandingkan dengan harapannya. Upaya untuk mewujudkan kepuasan pelanggan total bukanlah hal yang mudah, Mudie den Cottom (1997) menyatakan bahwa kepuasan pelanggan total tidak mungkin tercapai, sekalipun hanya untuk sementara waktu (Kempul, 2009). Selain itu Purwanto (2007) menjelaskan bahwa kepuasan dapat dirasakan siapa saja dalam menerima pelayanan kesehatan. Hal ini juga terjadi pada pasien dalam menerima jasa pelayanan di rumah sakit.

Menurut pendapat Budiastuti (2002) mengemukakan bahwa pasien dalam mengevaluasi kepuasan terhadap jasa pelayanan yang diterima mengacu pada beberapa faktor, antara lain mengacu pada kualitas produk atau jasa. Pasien akan merasa puas bila hasil evaluasi mereka menunjukkan bahwa produk atau jasa yang digunakan berkualitas.

Selain itu persepsi pasien terhadap kualitas poduk atau jasa dipengaruhi oleh dua hal yaitu kenyataan kualitas poduk atau jasa yang sesungguhnya dengan komunikasi perusahaan terutama Man dalam mempromosikan rumah sakitnya. Kualitas pelayanan memegang peranan penting dalam industri jasa. Pasien akan merasa puas jika mereka memperoleh pelayanan yang baik atau sesuai dengan yang diharapkan. Selain itu faktor emosional juga mempengaruhi pasien yang merasa bangga dan yakin bahwa orang lain kagum terhadap dirinya bila memilih rumah sakit yang sudah mempunyai pandangan "rumah sakit mahal". Persepsi pasien terhadap hal ini cenderung akan mempengaruhi tingkat kepuasan yang lebih tinggi.

Ada beberapa jenis pelayanan di rumah sakit yang kualitasnya selalu dinilai oleh pasien, dan salah satunya adalah pelayanan keperawatan. Tim Keperawatan merupakan anggota tim kesehatan garda depan yang menghadapi masalah kesehatan klien selama 24 jam secara terus menerus (Aljafar, 2009). Tim pelayanan keperawatan memberikan pelayanan kepada klien sesuai dengan keyakinan profesi dan standar yang ditetapkan. Hal ini ditujukan agar pelayanan keperawatan yang diberikan senantiasa merupakan yang aman serta dapat memenuhi kebutuhan dan harapan klien. Agar kebutuhan pasien 
terpenuhi, salah satu tindakan yang diharapkan adalah perawat dapat melakukan hubungan terapeutik dengan pasien. Untuk membina hubungan yang terapeutik perawat harus menguasai teknik dan sikap komunikasi terapeutik selama memberikan asuhan keperawatan kepada pasien (Kelliat, 1996).

Komunikasi terapeutik adalah suatu pengalaman bersama antara perawat - klien yang bertujuan untuk menyelesaikan masalah klien. Seorang perawat tidak akan dapat mengetahui kondisi klien jika tidak memiliki kemampuan menghargai keunikan klien. Tanpa mengetahui keunikan masing-masing, terutama terkait kebutuhan klien, perawat juga akan kesulitan memberikan bantuan kepada klien dan mengatasi masalah klien. Sehingga perlu metode yang tepat dalam mengakomodasi agar perawat mampu mendapatkan pengetahuan yang tepat tentang pasien. Melalui komunikasi terapeutik diharapkan perawat dapat menghadapi, mempersepsikan, bereaksi dan menghargai keunikan klien (Mundakir, 2006).

Berdasarkan hasil survey yang dilakukan peneliti di rumah sakit Martha Friska Medan, dengan teknik wawancara pada 10 pasien ditemukan beberapa keluhan dari pasien. Keluhan tersebut antara lain terkait dengan buruknya pelayanan perawat, sedikitnya kunjungan dokter pada pasien rawat inap. Buruknya pelayanan perawat yang dirasakan pasien terutama dari sikap, keramahan dan kemampuan komunikasi yang kurang santun.

Hasil penelitian melalui survey CRC (Citizen Report Card) ICW pada bulan November 2009 dengan sampel 738 pasien miskin (pasien rawat inap dan jalan yang memegang kartu Jaminan Kesehatan Masyarakat (Jamkesmas), Keluarga Miskin (Lakin) dan Surat Keterangan Tidak Mampu (SKIM)) di 23 rumah sakit yang ada di lima daerah (Jakarta, Bogor Depok, Tanggerang, Bekasi), menunjukkan bahwa pasien miskin menyatakan bahwa pengurusan administrasi rumah sakit masih rumit dan berbelit-belit (28,4 persen) dengan antrian yang panjang $(46,9 \%)$. Pasien rawat inap misalnya mengeluhkan rendahnya kunjungan dan disiplin dokter terhadap mereka. Sedangkan pasien perempuan rawat inap mengeluhkan sikap perawat yang kurang ramah dan simpatik terhadap mereka $(65,4 \%)$ (KPK Online Monitoring System, 2009).

Berdasarkan hasil penelitian sebelumnya kita dapat melihat bahwa ketidakpuasan pasien terhadap pelayanan kesehatan salah satunya dipengaruhi oleh faktor komunikasi terapeutik perawat dalam memberikan asuhan keperawatan. Banyak yang mengira atau berpendapat bahwa komunikasi terapeutik identik dengan senyum dan bicara lemah lembut. Pendapat ini tidak salah tetapi terlalu menyederhanakan arti dari komunikasi terapeutik itu sendiri, karena inti dari komunikasi terapeutik adalah komunikasi yang dilakukan untuk terapi (Suryani, 2005).

Adapun manfaat dari komunikasi terapeutik itu sendiri adalah membantu pasien dan untuk memperjelas dan mengurangi beban perasaan dan pikiran serta dapat mengambil tindakan untuk mengubah situasi yang ada bila pasien percaya dengan hal-hal yang diperlukan. Mengurangi keraguan, membantu dalam hal mengambil tindakan yang efektif dan mempertahankan egonya. Mempengaruhi orang lain, lingkungan fisik dan dirinya sendiri dalam hal peningkatan derajat kesehatan. Mempererat hubungan atau interaksi antara klien dengan terapis (tenaga kesehatan) secara profesional dan proporsional dalam rangka membantu penyelesaian masalah klien (Mundakir, 2006).

Berdasarkan studi literatur di atas, maka penulis tertarik untuk mengadakan penelitian tentang "Pengaruh Komunikasi Terapeutik Perawat Terhadap Kepuasan Pasien di Rumah Sakit Martha Friska Medan". 


\section{KERANGKA KONSEPTUAL}

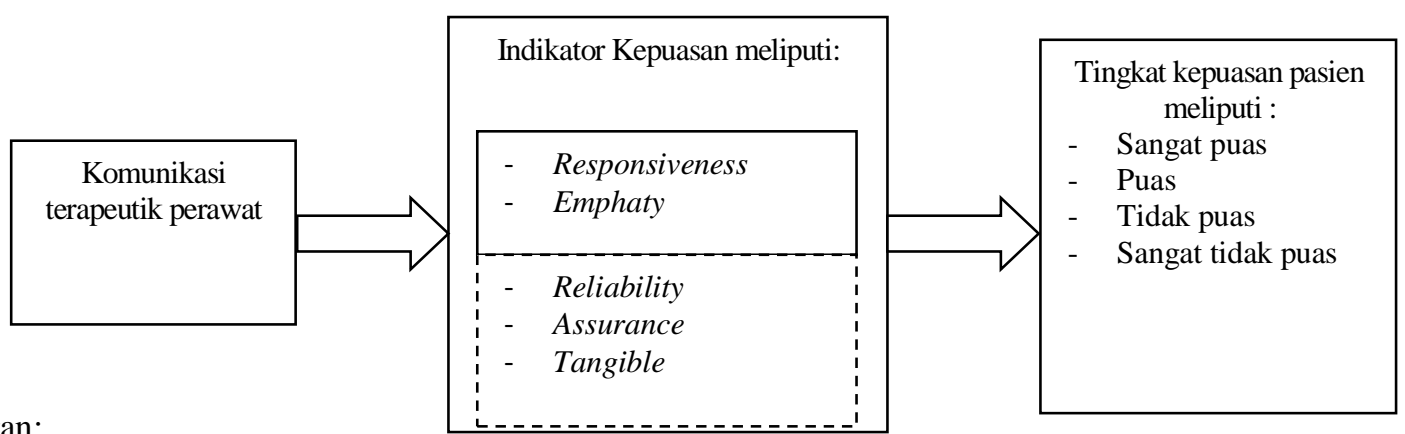

Keterangan:

$$
\begin{aligned}
& =\text { Diteliti } \\
& =\text { Tidak diteliti }
\end{aligned}
$$

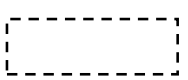

\section{Hipotesa Penelitian}

Hipotesa dalam penelitian ini adalah Hipotesis Alternatif (Ha), yaitu terdapat pengaruh diantara independen (komunikasi terapeutik perawat), dengan variabel dependen (tingkat kepuasan pasien).

\section{METODE PENELITIAN}

Jenis penelitian ini menggunakan desain studi korelasi yang bertujuan untuk mengidentifikasi pengaruh komunikasi terapeutik perawat terhadap kepuasan pasien rawat inap di rumah sakit Martha Friska Medan. Populasi dalam penelitian ini adalah seluruh pasien yang berobat rawat inap pada bulan Maret 2016 di rumah sakit Martha Friska Medan sebanyak 640 orang, yang dipilih dari beberapa ruangan rawat inap secara acak sampai mewakili populasi yaitu sebanyak 64 orang. Penelitian ini dilaksanakan pada bulan Januari sampai dengan Oktober 2016. Analisis data yang digunakan dalam penelitian ini adalah analisis univariat dan analisis bivariat. Analisis univariat untuk mendeskripsikan karakteristik setiap variabel yang diukur dalam penelitian dan analisa bivariat untuk melihat hubungan antara dua variabel independen (komunikasi terapeutik perawat), dengan variabel dependen (kepuasan pasien) dengan memakai Skala ordinal dengan uji korelasi Spearman Rank (Rho), untuk mengetahui tingkat kecocokan dari 2 variabel terhadap grup yang sama, dengan tingkat kepercayaan 95\% $(\alpha=0,05)$

\section{HASIL DAN PEMBAHASAN}

\section{Hasil Penelitian}

\section{Analisis Univariat}

Dari hasil observasi terhadap komunikasi terapeutik perawat terhadap kepuasan pasien di rumah sakit Martha Friska Medan tahun 2016, diperoleh hasil bahwa mayoritas responden berumur 41-45 tahun yaitu sebanyak 21 orang, dengan jenis kelamin mayoritas lakilaki yaitu sebanyak 40 orang $(62,5 \%)$. Suku responden mayoritas suku Jawa sebanyak 22 orang $(34,4 \%)$ dengan tingkat pendidikan mayoritas adalah pendidikan SLTA sebanyak 25 orang $(39,1 \%)$.

Berdasarkan variabel komunikasi terapeutik perawat, untuk sub variabel fase orientasi mayoritas 40 responden $(62,5 \%)$ sangat baik. Sub variabel fase kerja terdapat 34 responden $(53,1 \%)$ sangat baik, dan pada sub variabel fase terminasi mayoritas terdapat 39 responden $(60,9 \%)$ sangat baik.

Berdasarkan komunikasi terapeutik yang diterapkan oleh perawat saat berkomunikasi dengan pasien keterampilannya sangat baik sebanyak 43 responden $(67,2 \%)$.

Berdasarkan responsiveness / tanggapan sebanyak 51 responden $(79,7 \%)$, mengatakan sangat puas dan 13 pasien $(20,3 \%)$ merasa puas. Sedangkan berdasarkan empathy perawat dalam berkomunikasi terapeutik sebanyak 49 responden $(76,6 \%)$ juga mengatakan sangat puas.

Berdasarkan tingkat kepuasan responden mayoritas pasien merasa sangat puas terhadap respon dan empati perawat ketika berinteraksi dengan pasien sebanyak 55 pasien $(85,9 \%)$.

Hasil uji analisa dengan analisis korelasi sederhana (Spearman's Rho), pada penelitian ini menunjukkan nilai $\mathrm{r}=0,972$, nilai $\mathrm{p}$-value $=0,004$.

\section{Pembahasan}

a. Sub Variabel Fase Orientasi

Penelitian pada sub variabel orientasi didapatkan hampir seluruh perawat memperkenalkan diri saat berinteraksi dengan pasien (62,5), ada juga perawat yang tidak melakukannya tetapi sedikit hanya $(1,6 \%)$. Perawat yang tidak memperkenalkan diri terbatas pada menanyakan identitas pasien saja, perawat juga membuat kontrak terlebih dahulu sebelum berinteraksi dengan pasien.

Berarti keberhasilan/intervensi perawatan tergantung pada komunikasi karena proses keperawatan ditujukan untuk merubah perilaku 
mencapai tujuan.

\section{b. Sub Variabel Fase Kerja}

Pada sub variabel fase kerja, dari hasil penelitian didapatkan bahwa $34(53,1 \%)$ pasien mengatakan perawat melakukan komunikasi sangat baik yaitu perawat bertanya kepada pasien mengenai keluhannya berkaitan dengan pelaksanaan asuhan keperawatan dan menjalankannya dengan baik. Perawat juga memberi kesempatan pasien untuk bertanya sebelum tindakan dilaksanakan. Dan setelah selesai tindakan dilakukan evaluasi kerja dan disampaikan kepada pasien. Sesuai dengan pendapat Rosyidi (2008) mengatakan bahwa tugas perawat pada tahap kerja adalah mendorong ekspresi terbuka perasaan klien, membuat klien menyadari inkonsistensi dalam tingkah laku/pemikiran yang berhubungan dengan pemahaman diri.

\section{c. Sub Variabel Face Terminasi}

Fase terakhir atau perpisahan (terminasi) yang didapatkan dari penelitian menunjukkan bahwa komunikasi terapeutik perawat sangat baik 39 $(60,9 \%)$, perawat memberitahu pasien bahwa tindakan di ruang rawat inap selesai atau boleh pulang.

Menurut Mundakir (2006) pada fase ini perawat harus menciptakan realitas perpisahan, menyimpulkan hasil kegiatan, evaluasi hasil dan proses. Saling mengeksplorasi perasaan penolakan, kehilangan, sedih, marah dan perilaku lain. Memberikan reinforcement positif dan merencanakan tindak lanjut dengan klien. Melakukan kontrak untuk pertemuan selanjutnya (waktu, tempat, topik) serta mengakhiri kegiatan dengan baik. Fase ini merupakan fase yang sulit dan penting, karena hubungan saling percaya sudah terbina dan berada pada tingkat optimal. Perawat dan klien keduanya merasa kehilangan. Terminasi dapat terjadi pada saat perawat mengakhiri tugas pada unit tertentu atau saat klien akan pulang. Untuk melalui fase ini dengan sukses dan bernilai terapeutik, perawat menggunakan konsep kehilangan.

\section{1) Komunikasi Terapeutik yang Diterapkan Perawat saat Berkomunikasi dengan Pasien di Rumah Sakit Martha Friska Medan}

Berdasarkan hasil penelitian untuk variabel komunikasi terapeutik perawat dapat dilihat pada tabel 2 bahwa 43 pasien $(67,2 \%)$ merasakan bahwa komunikasi terapeutik yang diterapkan oleh perawat sangat baik. Hal ini terjadi karena perawat telah mampu merealisasi diri, membina hubungan interpersonal dengan klien serta memfasilitasi tumbuhnya hubungan yang terapeutik. Sesuai dengan yang dikatakan Roger (1997, dalam Stuart 1998) sesungguhnya karakteristik seorang perawat dapat memfasilitasi tumbuhnya hubungan terapeutik adalah kejujuran, tidak membingungkan dan cukup ekspresif bersikap positif, memiliki empati, dan menerima klien apa adanya.

\section{2) Karakteristik Variabel Kepuasan Pasien di Rumah Sakit Martha Friska Medan}

Berdasarkan hasil penelitian untuk variabel kepuasan pasien terdiri dari 2 sub variabel sebagai berikut :

\section{a) Sub Variabel Responsivenes}

Pada variabel responsiveness berdasarkan analisis penelitian menujukkan bahwa mayoritas pasien merasa, sangat puas dengan respon perawat ketika berinteraksi dengan pasien yaitu 79,7\%, dan yang merasa puas $20,3 \%$.

Hal ini menunjukkan bahwa keseluruhan pasien merasakan kepuasan yang tinggi terhadap responsiveness perawat rumah sakit Martha Friska Medan. Kepedulian perawat ini meliputi pasien tidak perlu menunggu lama untuk mendapatkan perawatan ketika pertama datang. Perawat selalu mengecek kesehatan pasien dan berinisiatif memanggil dokter jika terjadi perubahan kondisi tubuh pasien, perawat juga membantu pasien menjelaskan tentang yang dirasakan klien, memberikan obat tepat waktu yang telah ditentukan.

Dalam hai ini perawat berusaha memperhatikan kebutuhan pasien yang menjadi tanggung jawabnya, merespon permintaan mereka dengan tanggap, mendengarkan dengan serius apa yang pasien keluhkan serta menginformasikan jasa secara tepat. Menurut Supardi (2008). Responsiveness (ketanggapan), yaitu kemampuan petugas memberikan pelayanan kepada pasien dengan cepat.

Dalam pelayanan rumah sakit adalah lama waktu menunggu pasien mulai dari mendaftar sampai mendapat pelayanan tenaga kesehatan.

\section{b) Sub Variabel Empaty}

Pada sub variabel empati hasil penelitian menunjukkan $(76,6 \%)$ merasakan sangat puas terhadap empati perawat dalam memberikan pelayanan kepada pasien.

Hasil penelitian di rumah sakit Martha Friska Medan menunjukkan bahwa jumlah pasien yang merasakan perawat punya rasa empati dalam menjalankan tugas pelayanan asuhan keperawatan lebih banyak bila dibandingkan dengan pasien yang merasakan perawat kurang punya rasa empati. Bahkan hampir seluruh perawat berempati dalam menjalankan tugasnya terutama dalam hal perawat mengevaluasi perasaan pasien setelah berinteraksi dengannya. Walaupun terkadang pasien yang dirawat inap sangat banyak, perawat juga bersikap sopan, ramah dengan wajah yang tersenyum setiap bertemu dengan pasien, tidak membeda-bedakan status sosial, etnis, agama, serta 
status ekonomi pasien. Perawat juga memotivasi pasien untuk mengungkapkan perasaannya, terkadang yang menjadi kendala pada saat pergantian shift jaga perawat tidak sempat untuk melihat kondisi masing-masing pasien yang sedang menjalani perawatan karena perhatian perawat cenderung terfokus pada pasien yang kondisinya kritis, frekuensi interaksi perawat dengan pasien tergolong paling sering dibandingkan dengan tenaga kesehatan yang lainnya, maka keberadaan perawat di rumah sakit sangat penting dalam memegang peranan atas kelangsungan kondisi pasien.

Sesuai dengan pendapat Bratha (2008) Seorang perawat dengan empatinya akan membantu pasien. Perawat berkeharusan bersikap baik dan santun kepada seluruh pasien, baik itu bayi yang barn lahir sampai orang lanjut usia sekalipun. Sikap ini didasarkan pada pemikiran, pilihan sikap yang benar dan tepat dalam segala situasi, yaitu tempat dan waktu. Perawatan yang efektif mencakup pemberian perhatian kepada kebutuhan emosi sang pasien. Sikap perawat kepada pasien disesuaikan dengan usia pasien. Hal ini menguatkan bahwa kemampuan untuk dapat berempati sangat diperlukan sekali oleh perawat agar perawatan lebih efektif.

\section{d. Hubungan Komunikasi Terapeutik Perawat terhadap kepuasan pasien di Rumah Sakit Martha Friska Medan}

Dari hasil analisis penelitian dengan analisi korelasi Spearman's pengaruh antara komunikasi yang diterapkan oleh perawat di Rumah Sakit Martha Friska Medan. Pada penelitian menunjukkan nilai $r=0,004$. Yang berarti adanya korelasi yang tidak kuat dan dengan nilai $\mathrm{p}$-value $=0,972$ menunjukkan adanya pengaruh yang tidak signifikan antara komunikasi terapeutik perawat terhadap kepuasan pasien.

Peneliti menyimpulkan bahwa hipotesa dari penelitian ini ditolak karena terdapat pengaruh yang tidak signifikan komunikasi terapeutik perawat terhadap kepuasan pasien. Berbeda dengan penelitian sebelumnya yang dilakukan oleh Eva Alviana (2007), Universitas Muhammadiyah Semarang. Hasil dari penelitian ini menunjukkan bahwa :"Ada hubungan antara Komunikasi Terapeutik PerawatPasien dengan Kepusan Pasien terhadap Pelayanan Rumah Sakit AlIslam Bandung Berdasar hasil uji statistik diperoleh nilai $r=0,514$ dan $p=0,000$. Data ini menunjukkan bahwa hubungan tersebut signifikan pada taraf signifikansi 0.01 (lebih kecil dari 0,05). Nilai r sebesar 0,514 berarti kekuatan hubungan tersebut sedang atau moderat. Pola hubungan linier positif yang berarti semakin baik pelaksanaan komunikasi terapeutik maka pasien akan semakin merasa puas.

\section{KESIMPULAN DAN SARAN}

\section{Kesimpulan}

a. Komunikasi terapeutik perawat di rumah sakit Martha Friska Medan rata-rata sangat baik walaupun ada sebagian belum menggunakan komunikasi terapetik secara baik. Melalui tahapan komunikasi pada fase orientasi $(62,5 \%)$, dan fase kerja $(53,1 \%)$, dan pada fase terminasi $(60,9 \%)$

b. Kepuasan yang dirasakan pasien rawat inap di rumah sakit Martha Friska Medan pada umunya sangat puss terhadap respon yaitu $(79,7 \%)$ dan empati perawat $(76,8 \%)$ ketika berinteraksi dengan pasien dalam memberikan asuhan keperawatan.

c. Terdapat pengaruh yang tidak signifikan antara komunikasi terapeutik dengan kepuasan pasien di rumah sakit Martha Friska Medan. Hal tersebut menunjukkan bahwa hipotesa peneliti ditolak.

\section{Saran}

\section{a. Bagi perawat}

Agar dapat meningkatkan pelaksanaan komunikasi terapeutik dan kemampuan berkomunikasi terapeutik yang lebih baik lagi.

\section{b. Bagi pihak Rumah Sakit}

Untuk menerapkan SOP komunikasi terapeutik secara optimal diharapkan untuk meningkatkan pengetahuan perawat dengan cara mengikutsertakan para perawat dalam seminarseminar keperawatan tentang komunikasi terapeutik, memberikan pelatihan untuk meningkatkan sikap, empati perawat terhadap pasien, dan memberikan kesempatan perawat melanjutkan pendidikannya.

\section{c. Bagi peneliti selanjutnya}

Diharapkan pada peneliti selanjutnya untuk melibatkan responden yang lebih bayak lagi serta menggunakan indikator kepuasan yang lebih luas, seperti : Reliability (kehandalan), Assurance (jaminan), Tangible (bukti langsung). 


\section{DAFTAR PUSTAKA}

Arikunto, S. (2114), Prosedur Penelitian Suatu Pendekatan Prakiek, Rineka Cipta, Jakarta.

Alimun, H. Aziz. (2007), Riset Keperawatan Dan Teknik Penulisan Ilmiah. Salemba Medika. Jakarta

Dampsey \& Dempsey, (2002), Riset Keperawatan Buku Ajar dan Latihan, Edisi IV, EGC, Jakarta.

Keliat, Budi, Anna. (1996). Hubungan Terapuetik Perawat Klein. Penerbit Buku Kedoktoran, ECG. Jakarta.

Mundakir, (2006), Komunikasi Dalam Keperawatan : Aplikasi Teori dan Praktik. EGC. Jakarta.

Notoadmojo Soekidjo. (2012), Metodologi Penelitian Kesehatan. Rineka Cipta. Jakarta.

Notoatmojo, S. (2011), Metode Penelitian, Keperawatan. Rineka Cipta. Jakarta.

Nursalam, (2008). Konsep Dan Penerapan Metodologi Penelitian Ilmu Keperawatan. Salemba Medika. Jakarta.

Purwanto, Heri. (2007). Komunikasi Untuk Perawat. EGC, Jakarta.

Suryani. 2005. Komunikasi Terapeutik : Teori dan Praktik. EGC. Jakarta.

S. Pohan, Imbalo. (2006), Jaminan Mutu Layanan Kesehan. ECG. Jakarta.

Sudjana (1992). Statistik Penelitian. Tarsito. Bandung.

Stuart, G.W \& Sundeen S.J (1995), Pocket gide to Psychiatric Nursing. Third edition. St.Louis: Mosby Year Book.

Stuart, G.W.\& Sundeen S.J (1995).Principles and Practise of Psychiatric Nursing. St.Louis: Mosby Year Book.

Kempul.com. (2009). Kepuasan pasien terhadap pelayanan Rumah Sakit.

Sudibyo Supardi, (2007), apotekputer.com. Faktor yang berhubungan dengan kepuasan pasien rawat inap dan rawat jalan. 